\title{
LIST OF BOOKS AND PERIODICALS CITED
}

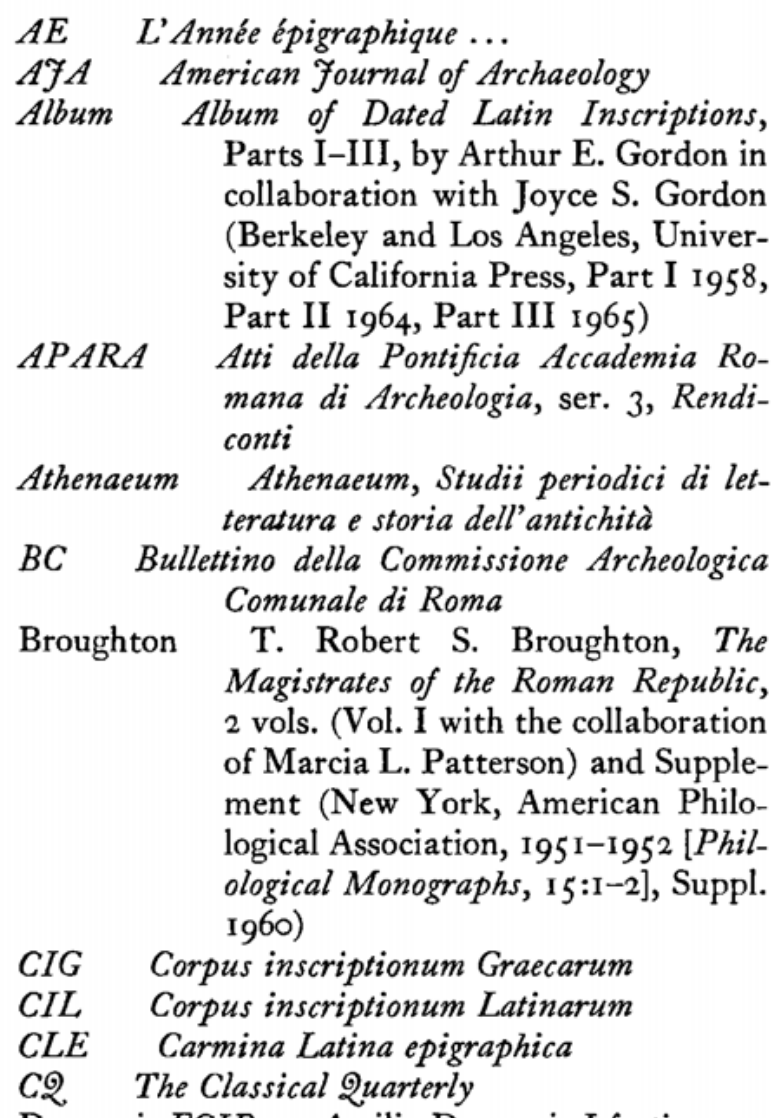

Degrassi, FCIR Attilio Degrassi, I fasti consolari dell' Impero romano dal 30 avanti Cristo al 6r3 dopo Cristo (Rome, 1952)

FCT Fasti consulares et triumphales, curavit Atilius Degrassi (Rome, 1947 [Inscr. Ital. I3:I])

ILLRP Inscriptiones Latinae liberae rei publicae, a cura di Attilio Degrassi, fasc. prior and alter (Florence, 1957, 1963)

De Rossi Inscriptiones Christianae urbis Romae septimo saeculo antiquiores, ed. Ioannes Bapt. De Rossi Romanus, Vol. I (Rome, I857-6I)

Dessau Inscriptiones Latinae selectae, ed. Hermannus Dessau, 3 vols. in 5 (Berlin, 1892-1916, and reprinted) (Cited occasionally as $I L S$ )
Diehl, ILCV Inscriptiones Latinae Christianae veteres, ed. Ernestus Diehl, 3 vols. (Berlin, 1924/25-1928/31, and reprinted)

DPARA Dissertazioni della Pontificia Accademia Romana di Archeologia

EE Ephemeris epigraphica... (Berlin)

Gordon, Contributions Joyce S. and Arthur E. Gordon, Contributions to the Palaeography of Latin Inscriptions (Berkeley and Los Angeles, I957 [Univ. Calif. Publ. Class. Arch. 3:3])

Gordon, Veranius Arthur E. Gordon, Quintus Veranius, Consul A.D. 49 ... (Berkeley and Los Angeles, $195^{2}$ [Univ. Calif. Publ. Class. Arch. 2:5])

Henzen Acta fratrum Arvalium quae supersunt, rest. et ill. Guil. Henzen ... (Berlin, 1874)

Hübner Exempla scripturae epigraphicae Latinae a Caesaris dictatoris morte ad aetatem Iustiniani . . ., ed. Aemilius Hübner (Berlin, 1885)

IG Inscriptiones Graecae

IGRR Inscriptiones Graecae ad res Romanas pertinentes, Vols. I, 3-4 (Paris, I90I1927)

Inscr. Ital. Inscriptiones Italiae (Rome, 1931-) Lewis and Short A Latin Dictionary ... by Charlton T. Lewis and Charles Short (now publ. at the Clarendon Press, Oxford)

Lugli Giuseppe Lugli, I Monumenti Antichi di Roma e Suburbio, Vol. 3 (Rome, 1938)

Nash Ernest Nash, Pictorial Dictionary of Ancient Rome, 2 vols. (London, 196162)

NS Notizie degli scavi di antichita (Atti dellAccademia [Nazionale] dei Lincei)

PIR Prosopographia imperii Romani saec. I. II. III., edd. E. Klebs, H. Dessau, and P. von Rohden, 3 vols. (Berlin, 1897-98), and ed. 2 of the same, Vols. I-4:2 (A-H) to date, edd. Edmund Groag, Arthur Stein, and 
others (Berlin [and Leipzig, Vols. I-3], 1933-58)

Platner-Ashby A Topographical Dictionary of Ancient Rome by Samuel Ball Platner, completed and revised by Thomas Ashby (Oxford and London, I929)

RE Pauly's Realencyclopädie der classischen Altertumswissenschaft, Neue Bearbeitung

Ritschl Priscae Latinitatis monumenta epigraphica ..., ed. Fridericus Ritschelius (Berlin, 1862)

Silvagni Inscriptiones Christianae urbis Romae septimo saeculo antiquiores, colligere coepit I. B. De Rossi, complevit ediditque Angelus Silvagni. Nova ser., Vol. I (Rome, I922), 2 (1935),
3 (1956-by Silvagni and Antonio Ferrua), with 2 vols. of plates, 1935 and 1956

Sinnigen William Gurnee Sinnigen, The Officium of the Urban Prefecture during the Later Roman Empire (Rome, I957 [Papers and Monographs of the American Academy in Rome, Vol. 17])

TLL Thesaurus linguae Latinae

Univ. Calif. Publ. Class. Arch. University of California Publications in Classical Archaeology

Walde-Hofmann A. Walde, Lateinisches etymologisches Wörterbuch, ed. 3 by J. B. Hofmann, Vol. 2 (Heidelberg, 1954)

Wissowa Georg Wissowa, Religion und Kultus der Römer, ed. 2 (Munich, I9I2) 